\title{
The Differentiation of Operation Characteristics and Land Management Rights Transfer: Evidence from China
}

\author{
Ziyu Zhang ${ }^{*}$, Hongting Shu \\ College of Big date application and Economics, Guizhou University of Finance and Economics, Guizhou, \\ Guiyang, China
}

Keywords: Operation characteristics, Differentiation, Land transfer, Rural China

\begin{abstract}
Based on the background of economic transition (transition from a planned economy to a market economy), from the perspective of occupation differentiation of rural households, this paper analyzes the current willingness and behavior mechanism of the land management rights transfer for different types of farmers, and use the micro-survey data for statistical analysis and empirical test. The study finds that: smallholders and new agricultural business entities mainly have strong willingness to transfer land, smallholders are difficult to rent in land due to the imperfect land rental market, while it is easier for new agricultural business entities to transfer land with government support. Part-time farmers intent to maintain current land scale, while urban farmers have a strong willingness to transfer land, however, current distorted grain subsidy policies and low rents do not encourage them to transfer their land. The enlightenment of this paper lies in: the Chinese government should establish and improve the incentive policies for various types of farmers' innovation and venture capital investment, promote the effective differentiation of rural farmers' occupations, improve the effective supply and demand levels of rural land circulation, and set up agricultural land circulation Internet trading platform; Accelerate the reform of the agricultural supply side, accelerate the establishment of an integrated urban and rural social security system, optimize the grain subsidy system, promote the orderly circulation of land and moderate agriculture scale operation.
\end{abstract}

\section{Introduction}

Driven by China's reform and opening-up and household register system reform, with accelerate process of industrialization and urbanization, the surplus rural labor force began to move into high-paying nonagricultural sectors in cities [1,2]. With off-farm employment increasing constantly, the operational characteristics of Chinese farmer started to differentiate. Some farmers who continue farming turn into new agricultural business entities [1] by accumulating funds, mastering advanced technology and improving their operations, while the others who lack of funds, advanced technology and management experience are still work as smallholders. Among the farmers who migrate to the urban areas, some of them have nonagricultural skills, may exit from agriculture and work in urban areas completely, are defined as non-farmers, drawing on the conclusion of Deininger et al. [3] The others who lack nonagricultural skills may become the part-time farmers [2], allocate their working hours between urban areas and rural areas based on output flattening effects. With constant differentiation of operational and occupational characteristics, the importance of land to different types of farmers has changed tremendously. On the one hand, land is still the most important productive factor for smallholders and new agricultural business entities, whose income mainly depend on agricultural operations, in addition, economies of scale also raise the demand for land. On the other hand, as for part-time farmers and non-farmers, their production and management dependence on agricultural land has decreased significantly, which may result in the transfer of agricultural land supply.. With the migration of agricultural labor force, Household Responsibility System (HRS) is no longer suitable for the economic development. It is urgent to improve land use efficiency by transferring land from those who move to non-farm sectors to those who continue farming, and then improve the effective allocation of cultivated land 
[4-6].

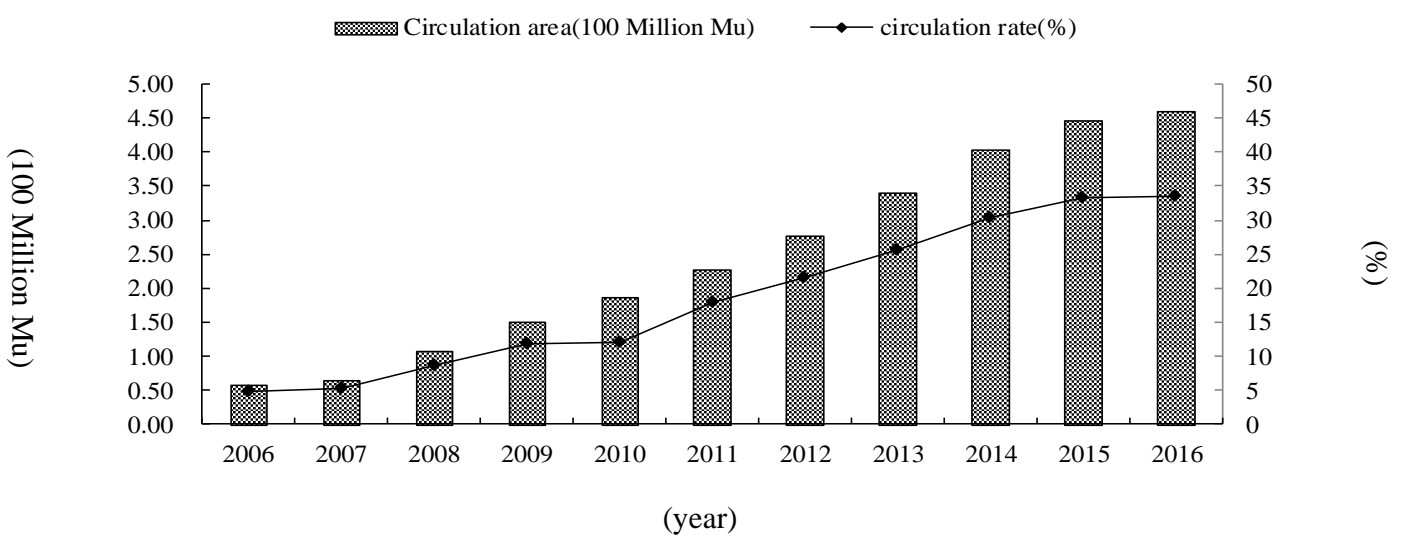

Figure 1 Cultivated land transfer area and transfer rate of China from 2006 to 2016.

Source: Chinese Ministry of Agriculture

Figure 1 shows the main trend of land transfer in China from 2006 to 2016. The share of land transfer [3] has increased significantly from 4.57 percent to 33.52 percent, and the transferred cultivated land areas were 460 million mu [4]. As is shown above, the scale and speed of land transfer has increased rapidly since 2010. . From 2014 to 2016, the "No. 1 Central Document" clearly pointed out: guide the orderly transfer of farmland management rights, innovate the pattern of land circulation methods, and actively develop various types of moderate-scale operations. However, the process of land transfer was restricted by the lagged process of farmer urbanization, the social security function of farmland, the relatively high transaction costs and so on. Therefore, based on farmers' operational and occupational differentiation perspective, different farmers' willingness to land circulation and behavior research, and then find out the organic convergence point of land transfer for various types of farmers, this will facilitate the effective reorganization of agricultural land resources in China, develop various forms of moderate scale management, and realize agricultural modernization, which has important theoretical significance and practical values.

Previous literature in this field focused on land tenure security, land transaction rights and the decision making by farmers, with the following representative works and findings. First, from the perspective of land tenure security, higher land tenure security will provide a reliable guaranty for long-term investment $[7,8]$. However, uncertain expectation on land tenure security limits long-term investment to achieve the optimum level, which leads to low land productivity and efficiency [3,9]. Zhu et al. [10], Huang [11], Gao et al. [12], and Cheng et al. [13] have found that the conclusion is still tenable in China. Second, in terms of land transaction rights, Qian [14] and Zhou [15] found that incomplete rental rights would also impede the farmers' long-term investment, and reduce the transfer income and land supply. Enhancing the efficiency of land rental rights will increase farmers' income by renting out their land, and make full use of idle land $[4,16]$. Third, in the complete market, farmers have perfect information and zero transaction cost, they can make the optimal land transfer choice [17]. However, as imperfections of land rental market, information asymmetry and transaction costs impede the land transfer, land transfer does not always achieve the optimum outcome [18]. In addition, even if the land rental market is perfect, farmers' transfer decisions are also impeded by other factors such as uncertain expectation about urban life, imperfection of credit market, and lack of social security system and health insurance system [19-22].

The aforementioned literature mainly focused on land transfer influenced by land tenure security, land transaction rights or farmers' decision-making. They hypothesized that farmers were homogeneous. In fact, very few literatures considered heterogeneity of farmers. However, with the agricultural labor force migration to the urban areas constantly, the operational characteristics differentiation of farmers has become an irreversible trend in China. Therefore, different operational characteristics will undoubtedly affect the intention and behavior of farmers in land transfer. In 
view of this, this paper will theoretically analyze the willingness and behavior of land transfer for different types of farmers under the assumption of "rational farmer households", and combine statistical analysis and empirical tests with micro survey data. The possible contributions of this paper are as follows: for one thing, it deduces the process of occupational differentiation of farmers in the context of economic transition, as well as the willingness and behavioral of land transfer of different occupational types; For another, it conducts directional measurement of the farmers' land transfer intention and behavior of different occupational types.

The rest of this paper is organized as follows. The theoretical framework is presented in section 2; Section 3 describes the data; Section 4 introduces the econometric model and reports the econometric results; Section 5 concludes by drawing out some implications for policy.

\section{The Model}

\subsection{The mechanism of the farmer operational characteristics differentiation}

In China, land has been redistributed to all households after the Household Contract Responsibility System (HRS) implemented in 1980s, and all the rural households became smallholders in the framework of HRS. We assume their total income ${ }^{I_{t}}$ is composed of two parts: direct income $I_{d}$ and indirect income $I_{i} I_{d}$ is determined by crop yields $Q_{a}$. We further assume that:

$$
Q_{a}=A f(K, L, S)
$$

where $A$ is technology and assumed to be constant, $K$ is capital, $L$ is labor, and $S$ is land area. $Q_{a}$ is divided into two parts: $Q_{c}$ and $Q_{s}$, where $Q_{c}$ denotes the part for self-consumption, and $Q_{s}$ denotes the part for sold. Then, the direct income $I_{d}$ is composed of three parts, the invisible income of self-consumption $I_{c}$, income from the sale of agricultural products $I_{s}$, and the agricultural subsidy $I_{f}$, as is shown in equation (2):

$$
I_{d}=I_{c}+I_{s}+I_{f}
$$

Assume that the price of crops is $P_{a}$, and agricultural subsidy is $P_{f}$ per mu, then $I_{d}$ can be written as follows:

$$
\begin{aligned}
I_{d} & =P_{a} Q_{c}+P_{a} Q_{s}+P_{f} S \\
& =P_{a} Q_{a}+P_{f} S
\end{aligned}
$$

Hence, ${ }^{I_{t}}$ can be written as

$$
\begin{aligned}
I_{t} & =I_{d}+I_{i} \\
& =P_{a} Q_{a}+P_{f} S+I_{i}
\end{aligned}
$$

Here, $I_{i}$ is composed of the social insurance, employment opportunities and family care provided by farmer households engaged in agriculture operations [23]. Under the condition that farmers can freely choose to work between urban and rural areas, smallholders would consider the productive cost $C_{p}$ and opportunity cost $C_{o}$, if they choose to work on the farmland, $C_{p}$ includes the wage paid for labor and the expenditure on product goods such as seeds, pesticides, fertilizers etc. Assume the price of production goods is $P_{m}$ per mu, and the labor price is $P_{l}$ per mu. Then, $C_{p}$ can be written as: 


$$
C_{p}=\left(P_{m}+P_{l}\right) S
$$

$C_{o}$ is the highest income that smallholders can get if they give up agricultural production, so the accounting profit of the farmer $E_{a}$ will be:

$$
E_{a}=I_{t}-C_{p}
$$

and the economic profit $E_{p}$ will be:

$$
\begin{aligned}
E_{p} & =E_{a}-C_{o} \\
& =I_{t}-C_{p}-C_{o}
\end{aligned}
$$

Before the urban and rural household registration system reform, smallholders were not allowed to work between urban and rural areas, they only engaged in involution agricultural production on the land, thus only cared about the accounting profit $E_{a}$ [24]. While after the Chinese government's reform of the Household Registration Systemin 1980s, Chinese farmers have opportunities to choose work between urban and rural areas for the maximum of $E_{p}$. The differentiation of operational characteristics started at the same time.

If $E_{p}>0$, i.e., the accounting profit $E_{a}$ is higher than the opportunity cost $C_{o}$, smallholders will continue to work on the farmland. Certainly, there also exists differentiation in the interior of smallholders. If the augment of the land, capital, labor and other elements are constrained, they will continue to work as smallholders. However, if the augment of those elements is not constrained, they will develop into new agricultural business entities such as big-specialized-households of crops and animal productions, household farms, cooperatives, and agricultural enterprises etc. The smallholders and new agricultural business entities are classified as full-time farmers.

If $E_{p}<0$, i.e., the accounting profit $E_{a}$ is lower than the opportunity cost $C_{o}$, farmers will give up farming (partly or completely), and begin to work in urban areas (partly or completely). If the farmers have nonagricultural professional skills with a relative high educational level, they will become non-farmers and work in urban areas completely. However, if the farmers lack nonagricultural skills, they will become part-time farmers and make job decisions based on the output flattening effect, that is, they will work on farming during busy farming season and become migrant workers during the slack periods. Part-time farmers and non-farmers are defined as non-full-time farmers.

\subsection{Land transfer of full-time farmers}

After the discussion of the operational characteristics differentiation mechanism in 2.1, the following part will continue discusses the land transfer course of these four types of farmers, the full-time farmers' land transfer decision-making mechanism will be analyzed in 2.2, and the non-full-time farmers' land transfer decision-making mechanism will be described in 2.3. For more simplicity , assume there is only one farmer of each type in the market.

As the advancement of agricultural technology, the smallholder's land scale is usually smaller than the economic scale, under the framework of HRS, he wants to rent in land to expand his operation scale. New agricultural business entity's operation scale is even bigger, thus he needs to transfer land much more. But from the perspective of maximizing economic profit, there exists an optimal scale point in their land transfer. We take smallholder as an example to analyze the land transfer decision-making mechanism of full-time farmers.

According to equation (6), the profit function [5] of smallholder is

$$
\begin{aligned}
P_{s} & =I_{s t}-C_{s p} \\
& =P_{a} A f\left(K_{s}, L_{s}, S_{s}\right)+P_{f} S_{s}+I_{s i}-\left(P_{m}+P_{l}\right) S_{s}
\end{aligned}
$$


Here, $I_{s t}$ is the total income of smallholder, $C_{s p}$ is the productive costs of smallholder. Hence, the first order condition for profit maximization with respect to scale will be:

$$
P_{a} A \frac{\partial f\left(K_{s}, L_{s}, S_{s}\right)}{\partial S_{s}}=P_{m}+P_{l}-P_{f}
$$

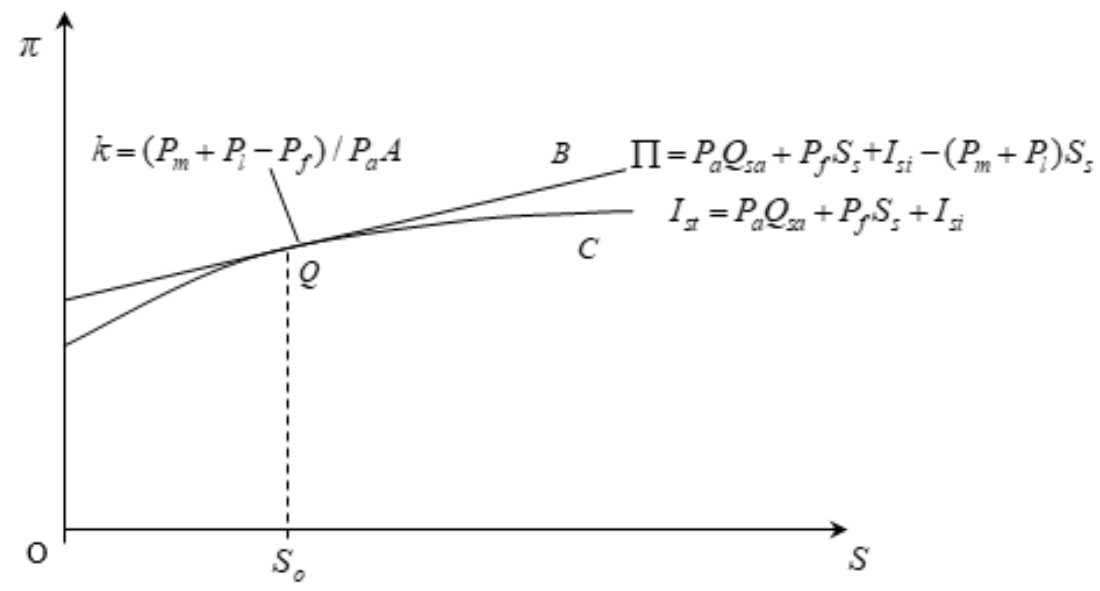

Figure 2 The Relationship between Land Scale and Output under the Condition of Profit Maximization.

We show the first-order conditions in Figure 2. Curve $C$ is the Production possibility frontier of smallholder, line B is the profit line of him, Q is the tangent point of the production possibility frontier and profit line.

As shown in Figure2, $S_{o}$ is the optimal scale which can be solved according to Equation (9). If $S=S_{o}$, marginal revenue is equal to marginal cost, returns to scale are unchanged; If $S \in\left[0, S_{o}\right.$ ), marginal revenue is greater than marginal cost, returns to scale start to increase gradually; If $S \in\left[S_{o}, \infty\right)$, marginal revenue is lower than marginal cost, returns to scale begin to diminish. After deducing the optimum land scale of smallholder, the land transfer boundary will be discussed according to the relationship between the current scale and the optimal scale, which is shown in Figure 3.

(1) If $S \in\left[0, S_{o}\right)$, marginal revenue of smallholder is greater than marginal cost, returns to scale increase gradually, he will expand scale and rent in land.

(2) If $S=S_{o}$, marginal revenue of smallholder is equal to marginal cost, returns to scale are constant, he will remain the scale, neither rent in nor rent out.

(3) If $S \in\left[S_{o}, \infty\right)$, marginal revenue is lower than marginal cost, returns to scale begin to diminish, he will reduce the land scale and rent out land.

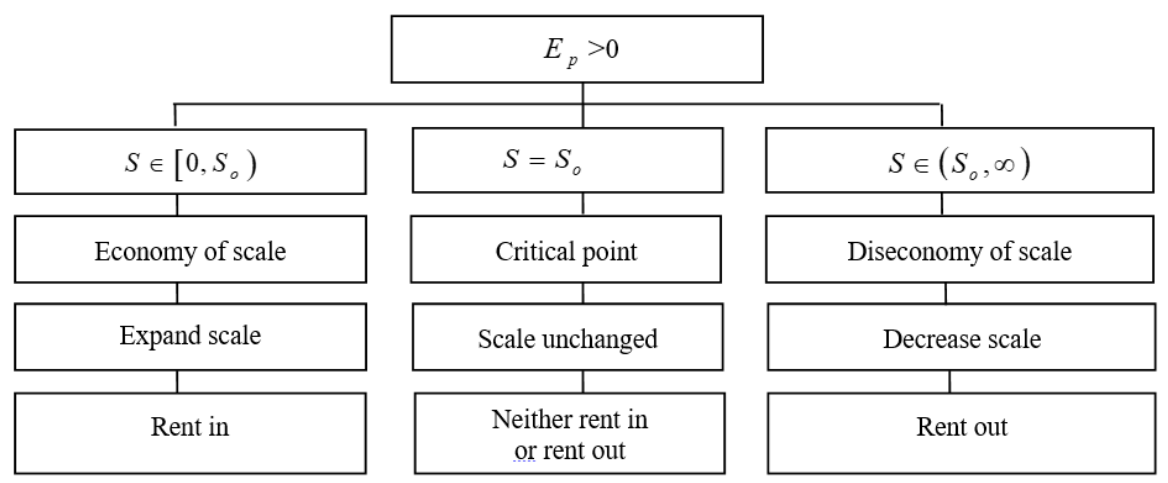

Figure 3 Land transfer intention of smallholder. 


\subsection{Land transfer of non-full-time farmers}

Part-time farmer can get relatively high nonagricultural income if he obtains off-farm employment, the proportion of agricultural income to total income will decrease gradually. It is not the optimal scale but the relationship between marginal output in agricultural sector and wage in nonagricultural sector becomes the key factor of land transfer.

Assume that the farmer's total work time is $t$, the time he allocates to nonagricultural sector is $t_{n}$, the time he allocates to agricultural sector is $t_{a}, t=t_{n}+t_{a}$, and wage in nonagricultural sector is

$w_{n}$. Hence, his profit function can be written as follows:

$$
P_{p}=P_{a} A f\left(K_{p}, L_{p}, S\left(t_{a}\right)\right)+P_{f} S_{p}+I_{i p}-\left(P_{m}+P_{l}\right) S\left(t_{a}\right)+w_{n} t_{n}
$$

Assume the marginal output in agricultural sector is $M P_{a}$. According to the equation (10), part-time farmer will allocate $t_{a}$ and $t_{n}$ based on the relationship between $M P_{a}$ and $w_{n}$. Once $t_{a}$ is decided, his optimal land scale $S\left(t_{a}\right)$ will also be decided, then he will make his land transfer decision according to the relationship between his current scale $S_{p}$ and optimal scale $S\left(t_{a}\right)$ : if $S_{p}$ is bigger than $S\left(t_{a}\right)$, he will try to rent out land; if $S_{p}$ is smaller than $S\left(t_{a}\right)$, he will try to rent in; if $S_{p}$ is equals to $S\left(t_{a}\right)$, he will neither rent out nor rent in.

Non-farmer has exit from the agricultural sector completely. ,his business has nothing to do with land. Without other restrictions, he absolutely wants to rent out his land completely. However, use of land as a key safety net and source of old-age support with few substitutes, limited rent, asymmetric information, and complex procedures caused by lack of land rental market will impede him from renting out.

Above all, the process of how farmers stratified into smallholder, new agricultural business entity, non-farmer and part-time farmer, and their land transfer intention and behavior mechanism have been described. Based on the analysis above, hypotheses are proposed as followings.

Hypothesis 1: For smallholder, in the framework of HRS, his current operating scale is usually smaller than the optimal scale, and he is more willing to rent in. However, the information asymmetry and the high transaction costs caused by imperfect land rental market may hinder his transfer behavior.

Hypothesis 2: As the efficient land scale is bigger than smallholder, rent in intention of new agricultural business entity is stronger than smallholder. In addition, new agricultural business entity can afford relatively high land rent, and is supported by government, thus he can rent in land much easier.

Hypothesis 3: With the increasing of non-farm wage, part-time farmer inclines to allocate more work time to nonagricultural sector, he may tend to rent out land at some extent. Meanwhile, in the view that his work time devoted into agricultural sector is limited, he is unlikely to rent in.

Hypothesis 4: Non-farmer has exit from the agricultural sector completely, his business has nothing to do with land, his rent out intention is strongest theoretically. However, social security function of land, limited rent, asymmetric information and complex procedures caused by lacking land rental market may put a negative incentive for his rent out behavior.

\section{The Data}

The data in this study is obtained from the Factor Agglomeration and Farmers' Income Growth in Rural China Survey. The survey was conducted by Southwest University in 2014 which covers 17 provinces (Includes Jilin, Liaoning, Shandong, Zhejiang, Jiangsu, Fujian, Guangxi, Shanxi, Anhui, Henan, Hubei, Hunan, Shaanxi, Gansu, Sichuan, Chongqing, Guizhou). 4 to 5 counties were selected from each province and 1 to 2 villages were selected form each county. A sample of 
3162 households is obtained. Provinces and counties were chosen based on representativeness, and villages and households were sampled randomly from name lists. The questionnaire recorded detailed information on transfer intention and transfer behavior of 2013, which are the key variables for our purposes. All variables' definitions and summary statistics are shown in Table 1 below.

Table 1 Variables definitions and summary statistics

\begin{tabular}{|c|c|c|c|c|c|}
\hline Variables & Definition & Mean & Std & Min & Max \\
\hline $\begin{array}{l}\text { Rent in } \\
\text { intention }\end{array}$ & $\begin{array}{c}=1 \text {, if a family wants to rent in land but } \\
\text { hasn't rent in, } 0 \text { otherwise }\end{array}$ & 0.11 & 0.31 & 0 & 1 \\
\hline $\begin{array}{l}\text { Rent out } \\
\text { intention }\end{array}$ & $\begin{array}{c}=1 \text {, if a family wants to rent out land but } \\
\text { hasn't rent out, } 0 \text { otherwise }\end{array}$ & 0.24 & 0.43 & 0 & 1 \\
\hline $\begin{array}{l}\text { Rent in } \\
\text { behavior }\end{array}$ & $\begin{array}{c}=1 \text {, if a family has rented in land, } 0 \\
\text { otherwise }\end{array}$ & 0.08 & 0.27 & 0 & 1 \\
\hline $\begin{array}{l}\text { Rent out } \\
\text { behavior }\end{array}$ & $\begin{array}{c}=1 \text {, if a family has rented out land, } 0 \\
\text { otherwise }\end{array}$ & 0.14 & 0.37 & 0 & 1 \\
\hline Smallholder & $\begin{array}{c}=1 \text {, if the household farm for living, and } \\
\text { land scale is less than } 50 \mathrm{Mu}, 0 \\
\text { otherwise }\end{array}$ & 0.18 & 0.39 & 0 & 1 \\
\hline $\begin{array}{c}\text { New } \\
\text { agricultural } \\
\text { business entity }\end{array}$ & $\begin{array}{c}=1 \text {, if the household farm for living, and } \\
\text { land scale is more than } 50 \mathrm{Mu}, 0 \\
\text { otherwise }\end{array}$ & 0.07 & 0.24 & 0 & 1 \\
\hline $\begin{array}{l}\text { Part-time } \\
\text { farmer }\end{array}$ & $\begin{array}{l}=1 \text {, if the household work on farming } \\
\text { during busy farming season and work in } \\
\text { non-farming industry during the other } \\
\text { time of the year, } 0 \text { otherwise }\end{array}$ & 0.49 & 0.50 & 0 & 1 \\
\hline Non- farmer & $\begin{array}{c}\text { =1, if the household work } \\
\text { in non-farming sector in urban } \\
\text { throughout the year. } 0 \text { otherwise }\end{array}$ & 0.26 & 0.44 & 0 & 1 \\
\hline Gender & $\begin{array}{c}\text { Gender of household-head, male }=1 \text {, } \\
\text { female }=0\end{array}$ & 0.93 & 0.26 & 0 & 1 \\
\hline Age & Age of household-head & 48.10 & 11.03 & 20 & 86 \\
\hline Education & $\begin{array}{c}\text { Education level of household-head: the } \\
\text { illiterate=1; primary school=2; junior } \\
\text { middle school=3; high school=4; college } \\
\text { and above=5 }\end{array}$ & 2.76 & 0.93 & 1 & 5 \\
\hline Family size & The number of family members & 4.27 & 1.33 & 1 & 10 \\
\hline $\begin{array}{l}\text { Agricultural } \\
\text { income }\end{array}$ & Household agriculture Income & $\begin{array}{c}15825.2 \\
0\end{array}$ & 63717.30 & 0 & $1.5 \mathrm{e}+07$ \\
\hline $\begin{array}{l}\text { Nonagricultur } \\
\text { al income }\end{array}$ & Household non-agriculture Income & 58261.7 & 90040.8 & 0 & $1.6 \mathrm{e}+07$ \\
\hline Fixed assets & Housing Value & $\begin{array}{c}183157 . \\
70\end{array}$ & 406190.60 & 2000 & $1.0 \mathrm{e}+07$ \\
\hline $\begin{array}{c}\text { Water } \\
\text { endowment }\end{array}$ & $\begin{array}{l}\text { Water richness of village, scarcity }=1 ; \\
\text { general }=2 ; \text { abundance }=3\end{array}$ & 2.24 & 0.59 & 1 & 3 \\
\hline $\begin{array}{l}\text { Geographical } \\
\text { endowment }\end{array}$ & $\begin{array}{l}\text { Geographical endowment of the village, } \\
\text { Mountainous area=1; Hilly area=2; Plain } \\
\text { area }=3\end{array}$ & 1.96 & 0.83 & 1 & 3 \\
\hline Land scale & Household land scale & 5.02 & 6.84 & 0 & 80 \\
\hline $\begin{array}{c}\text { Communist } \\
\text { Party member }\end{array}$ & $\begin{array}{l}=1 \text {, if the household has Communist } \\
\text { Party members, } 0 \text { otherwise }\end{array}$ & 0.21 & 0.41 & 0 & 1 \\
\hline $\begin{array}{l}\text { Expenditures } \\
\text { on gifts }\end{array}$ & Household expenditures on gifts & 4091.60 & 5065.20 & 50 & 50000 \\
\hline $\begin{array}{c}\text { Traffic } \\
\text { condition }\end{array}$ & $\begin{array}{c}\text { Type of the village main road, dirt } \\
\text { road=1; gravel road=2; cement road=3; } \\
\text { tar road=4 }\end{array}$ & 2.73 & 0.92 & 1 & 4 \\
\hline $\begin{array}{c}\text { Local } \\
\text { development } \\
\text { level }\end{array}$ & Per capita GDP of the province & $\begin{array}{c}40572.4 \\
0\end{array}$ & 13007.90 & 22862 & $\begin{array}{c}74515.8 \\
0\end{array}$ \\
\hline
\end{tabular}


Table 2 below illustrates the distribution of different types of farmers, their income structure and land areas. As is known, land has been redistributed to all households equally after HRS implemented in 1980s, all the rural households were smallholders (average land area is smaller than $0.5 \mathrm{ha}$ ) at that time, as the development of economic and household register system reform, urban areas can supply more and more off-farm work for agricultural labor force. Because non-agricultural wage is much higher than agricultural wage, many farmers choose to work in nonagricultural sector. The labor force engaged in agricultural production has decreased by about 300 million in the past 30 years. The trend of non-agriculturalization has already become obvious in China. According to our data, there are 2372 (or 75 percent of the sample) non-full time households, among them, 835 households (or 35.20 percent) have exited from the agricultural sector completely, their dependence on agricultural income have decreased tremendously. Hence, land is not an important productive factor for them, and they may have rent out intention. For full time farmers, agricultural income constitutes the vast majority of their income, land is still an critical productive factor for them, as their land areas are usually small under the framework of HRS, land area per capita of smallholder is only $1.84 \mathrm{mu}$ (less than $0.2 \mathrm{ha}$ ), even for new agriculture is less than $60 \mathrm{mu}$ (4 ha), they may have rent in intention.

Table 2 Distribution of different types of farmers, income structure, land area.

\begin{tabular}{|c|c|c|c|c|c|}
\hline & Households & Ration & $\begin{array}{c}\text { Average } \\
\text { income } \\
\text { (Yuan) }\end{array}$ & $\begin{array}{c}\text { Nonagricultural } \\
\text { income ratio }\end{array}$ & $\begin{array}{c}\text { Per capita } \\
\text { land area } \\
\text { (Mu) }\end{array}$ \\
\hline Smallholder & 591 & 18.69 & 11787.59 & 0.18 & 1.84 \\
\hline $\begin{array}{c}\text { New } \\
\text { agricultural } \\
\text { business entity }\end{array}$ & 199 & 6.29 & 25055.19 & 0.27 & 51.61 \\
\hline $\begin{array}{c}\text { Part-time } \\
\text { farmer }\end{array}$ & 835 & 26.41 & 19328.76 & 0.74 & 0.98 \\
\hline Non-farmer & 1537 & 48.61 & 37949.03 & 0.88 & 0.76 \\
\hline
\end{tabular}

Table 3 shows statistics results of land transfer willingness and behavior after farmers' occupational differentiation. Among the 3162 households, 1105 households have land transfer intention without transferred land yet, accounting for 34.89 percent of the sample. Among them, 347 households have rent in intention, most of whom are smallholders and new agricultural business entities. 758 households have rent out intention, most of whom are non-full time farmers. 752 households have transferred land, accounting for 23.74 percent of the total numbers of samples. The quantity of households who rent in farmland are 237, most of them are full time farmers. The quantity of households who rent out farmland are455, a majority of them are non-full-time farmers. There are 1368 households neither have transfer intention nor transfer behavior, accounting for 43.26 percent. Overall, farmers' land transfer intention is relatively strong, but the transfer behavior does not take place correspondingly. In terms of transfer direction, land rent out intention and behavior are higher than those of rent in. Full time farmers prefer to rent in farmland, while non-full-time farmers tend to rent out.

Table 3 Land transfer intention and behavior of different types of farmers.

\begin{tabular}{|c|c|c|c|c|}
\hline Farmer type & Rent in intention & Rent in behavior & Rent out intention & Rent out behavior \\
\hline Smallholder & 110 & 47 & 68 & 42 \\
\hline New agricultural business entity & 78 & 89 & 33 & 45 \\
\hline Non-farmer & 28 & 3 & 154 & 270 \\
\hline Part-time farmer & 131 & 98 & 503 & 98 \\
\hline
\end{tabular}




\section{Results and Discussion}

\subsection{Econometric model}

The following probit model is used to test the hypothesis 1 to hypothesis 4 :

$$
R_{i j}=\alpha_{i j}+\beta_{i j} h_{i j}+\text { cons }_{i j}+\mu_{i j}
$$

where $\alpha_{i j}$ denotes the fixed effect; $R$ denotes land transfer; hou , farmer operational characteristics; cons, a set of control variables; $\mu$, the error term; subscript ${ }^{i=1,2}$ (1 denotes transfer intention and 2 denotes transfer behavior); subscript $j=1,2,3,4$ (1 denotes smallholder, 2 denotes new agricultural business entity, 3 denotes part-time farmer, 4 denotes non-farmer).

\subsection{Land transfer of full time farmers}

Table 4 The rent in intention and behavior of full time farmers.

\begin{tabular}{|c|c|c|c|c|}
\hline \multirow[b]{2}{*}{ Variables } & \multicolumn{2}{|c|}{ Smallholders } & \multicolumn{2}{|c|}{ New agricultural business entities } \\
\hline & $\begin{array}{c}\text { Rent in } \\
\text { intention }\end{array}$ & Rent in behavior & Rent in intention & Rent in behavior \\
\hline Smallholder & $0.46^{* *}(1.99)$ & $0.58(1.05)$ & - & - \\
\hline New agricultural business entity & - & - & $1.48 * * *(4.87)$ & $1.96 * * *(6.63)$ \\
\hline Gender & $0.59(1.14)$ & $0.17(0.31)$ & $0.73(1.31)$ & $0.29(0.53)$ \\
\hline Age & $-0.03^{* * *}(-3.15)$ & $-0.02 * *(-2.53)$ & $-0.03(-1.01)$ & $0.02(1.24)$ \\
\hline Education & $-0.19(-1.50)$ & $-0.17(-1.24)$ & $-0.26 *(-1.91)$ & $-0.22(-1.58)$ \\
\hline Family size & $-0.09(-1.23)$ & $0.14 *(1.69)$ & $-0.12(-1.57)$ & $0.04(0.51)$ \\
\hline Agricultural income & $0.014(0.50)$ & $0.01(0.47)$ & $0.01(0.37)$ & $0.01(0.12)$ \\
\hline Nonagricultural income & $-0.01(-0.08)$ & $0.05(1.08)$ & $0.01(0.28)$ & $0.08(1.44)$ \\
\hline Fixed assets & $-0.02(-0.37)$ & $0.15 *(1.80)$ & $-0.06(-1.03)$ & $0.09(1.16)$ \\
\hline Water endowment & $0.02(1.11)$ & $0.24(0.88)$ & $0.14(0.60)$ & $0.14(0.52)$ \\
\hline Geographical endowment & $0.97 * * *(6.18)$ & $0.36 * *(2.45)$ & $1.01 * * *(6.23)$ & $0.45 * * *(2.74)$ \\
\hline Land scale & $0.15^{* * *}(5.10)$ & $0.08 * * *(2.74)$ & $0.16 * * *(5.76)$ & $0.08 * * *(3.11)$ \\
\hline Communist Party member & $0.55^{* * *}(2.12)$ & $-0.33(-0.99)$ & $0.60 * *(2.27)$ & $-0.23(-0.70)$ \\
\hline Expenditures on gifts & $-0.03(-0.38)$ & $-0.45(-0.15)$ & $-0.02(-0.25)$ & $-0.36(-1.47)$ \\
\hline Local development level & $-0.83^{* *}(-2.19)$ & $-0.06(-0.15)$ & $-0.95 * *(-2.41)$ & $-0.61(-1.37)$ \\
\hline Traffic condition & $-0.28 * *(-2.15)$ & $-0.09(-0.68)$ & $-0.28 * *(-2.30)$ & $-0.12(-0.82)$ \\
\hline Con & $6.32(1.69)$ & $-3.32(-0.78)$ & $8.26 * *(2.12)$ & $2.65(0.61)$ \\
\hline Pseudo R2 & 0.15 & 0.18 & 0.17 & 0.15 \\
\hline
\end{tabular}

Note: The value in parentheses is the p-value of the regression coefficient, * significance at 10 percent level, ${ }^{* *}$ significance at 5 percent level, ***significance at 1 percent level.

Table 4 above shows that the variable smallholder has a positive and significant impact on rent in intention, smallholder has a positive effect on land transfer behavior, but not significant. Land is an important productive factor to smallholders, while per capita land scale is relatively small in the framework of HRS, so they want to rent in. However, in the absence of land rental market, asymmetric information and high transaction costs will hinder smallholders from renting in. Further survey on smallholders who want to rent in land but haven't was conducted, the results show that 51 farmers do not know others who wants to rent out farmland, which accounting for 46.36 percent of the sample; 56 farmers consider that negotiating with other farmers are difficult, which accounting for 50.91 percent. These facts show that the asymmetric information and high transaction costs lead to higher marginal cost of land rent out behavior than marginal revenue. Facts above verify the truth of hypothesis 1 .

Table 4 also illustrates the s new agricultural business entity has a positive and significant effects on the intention and behavior of land rent in. Considering that their land scale is lower than the economy scale, new agricultural business entities are eager to rent in. New agricultural business entities have a relative high probability than smallholders due to their specialized production, as 
well as they can afford relatively high land rent. In addition, to facilitate land consolidation, government also provides policy support for new agricultural business entities in our survey areas, policy support generally includes: 1) providing loan guarantee service and subsidized loans for land rental payments and purchasing inputs when farm size is expected; 2) investment subsidies in the irrigation, drainage and storage infrastructures, insurance purchasing on large machineries and agricultural. These facts verify the validity of hypothesis 2 .

Table 5 The rent out intention and behavior of full time farmers.

\begin{tabular}{|c|c|c|c|c|}
\hline \multirow{2}{*}{ Variables } & \multicolumn{2}{|c|}{ Smallholders } & \multicolumn{2}{|c|}{ New agricultural business entities } \\
\hline & Rent out intention & Rent out behavior & Rent out intention & Rent out behavior \\
\hline Smallholder & $-0.85^{* * *}(-4.19)$ & $-0.60 * *(-2.35)$ & - & - \\
\hline New agricultural business entity & - & - & $-0.60 * *(-2.25)$ & $-0.06(-0.24)$ \\
\hline Gender & $-0.41(-1.55)$ & $-0.16(-0.47)$ & $-0.37(-1.39)$ & $-0.12(-0.33)$ \\
\hline Age & $-0.01(-1.28)$ & $0.01(1.15)$ & $-0.01 * *(-2.00)$ & $0.01(0.80)$ \\
\hline Education & $0.01(0.05)$ & $-0.05(-0.49)$ & $0.02(0.25)$ & $-0.04(-0.46)$ \\
\hline Family size & $0.01(0.21)$ & $-0.06(-0.94)$ & $0.01(0.10)$ & $-0.06(-1.01)$ \\
\hline Agricultural income & $0.0022(0.12)$ & $-0.0013(-0.06)$ & $0.0020(0.11)$ & $-0.0046(-0.20)$ \\
\hline Nonagricultural income & $-0.01(-0.26)$ & $-0.01(-0.14)$ & $-0.01(-0.47)$ & $-0.01(-0.28)$ \\
\hline Fixed assets & $0.06(1.51)$ & $0.17 * *(2.31)$ & $0.09 * *(1.99)$ & $0.19 * *(2.51)$ \\
\hline Water endowment & $-0.15(-1.09)$ & $-0.29(-1.70)$ & $-0.12(-0.93)$ & $-0.27(-1.64)$ \\
\hline Geographical endowment & $0.16(1.49)$ & $0.87 * * *(6.56)$ & $0.22 * *(2.09)$ & $0.90 * * *(7.00)$ \\
\hline Land scale & $-0.03(-1.02)$ & $-0.14 * * *(-3.67)$ & $-0.05(-1.54)$ & $-0.16 * * *(-4.11)$ \\
\hline Communist Party member & $0.16(0.90)$ & $0.01(0.08)$ & $0.17(0.96)$ & $0.02(0.11)$ \\
\hline Expenditures on gifts & $0.12 * *(2.17)$ & $-0.03(-0.54)$ & $0.13^{* *}(2.30)$ & $-0.01(-0.29)$ \\
\hline Local development level & $-0.33(-1.20)$ & $0.04(0.15)$ & $-0.31(-1.11)$ & $0.03(0.10)$ \\
\hline Traffic condition & $0.20 * * *(2.63)$ & $0.11(1.09)$ & $0.19 * *(2.49)$ & $0.10(1.04)$ \\
\hline Con & $1.25(0.44)$ & $-4.93(-1.41)$ & $0.68(0.24)$ & $-5.07(-1.44)$ \\
\hline Pseudo R2 & 0.15 & 0.10 & 0.13 & 0.19 \\
\hline
\end{tabular}

Table 5 above reports the estimates of rent out intention and behavior of full time farmers. Smallholder has a negative and significant impact on rent out intention, as well as rent out behavior. Land is not only an important factor of production, but also has social security function for smallholders. Smallholders are very cautious about land transfer and will not rent out without other insurances. New agricultural business entity is also shown to have a negative and significant impact on land rent out intention, they have a negative effect on land rent out behavior but not significant. The scale of land management is highly correlated with the income of new agricultural business entity, the new-type agricultural business entity is still in its early stages of growth, and scale of the land management is in the range of increasing returns, therefore, they will not choose to transfer out the land.

\subsection{Land transfer of non- full-time farmers}

As Table 6 shows, part-time farmer has a positive but not significant impact on both land rent out intention and behavior. As China's non-agricultural industry's labor force prices have risen in recent years, the comparative advantage of non-agricultural operation is more prominent. Part-time farmers tend to devote more time to work in urban area. In addition, constrained by the high transaction costs caused by imperfect land transfer and the prominent social security functions of land, part-time farmers still have no obvious land transfer behavior. Further survey was conducted on part-time farmers who want to rent out but haven't. According to our survey, there are 143 farmers who do not know others who want to rent in land, 218 farmers hold the option that negotiate with other farmers are difficult, and 212 farmers think the land rent out price are too low, which account for 28.42 percent, 43.33 percent and 42.14 percent of the sample respectively. These results verify that asymmetric information, high transaction costs and low rentsstill seriously restrict the rent out land. In addition, social security function of land is also an important reason to restrict 
rent out behavior. Specifically, 126 farmers worry about that they cannot receive the rents finally, and 84 farmers think it is hard to reclaim the land after they rent out, which accounting for 25.04 percent and 16.69 percent respectively. Results above verify the accuracy of hypothesis 3 .

Table 6 The rent out intention and behavior of non-full-time farmers.

\begin{tabular}{|c|c|c|c|c|}
\hline \multirow{2}{*}{ Variables } & \multicolumn{2}{|c|}{ Part-time farmers } & \multicolumn{2}{|c|}{ Non-farmers } \\
\hline & Rent out intention & Rent out behavior & Rent out intention & Rent out behavior \\
\hline Part-time farmer & $0.22(1.04)$ & $0.51(0.81)$ & - & - \\
\hline Non-farmer & - & - & $0.62 * * *(3.88)$ & $0.25(1.01)$ \\
\hline Gender & $-0.36(-1.34)$ & $-0.21(-0.60)$ & $-0.28(-1.03)$ & $-0.19(-0.54)$ \\
\hline Age & $-0.01 *(-1.67)$ & $0.01(0.58)$ & $-0.01 * *(-2.26)$ & $0.01(0.54)$ \\
\hline Education & $0.01(0.23)$ & $-0.07(-0.64)$ & $0.01(0.06)$ & $-0.07(-0.65)$ \\
\hline Family size & $0.06(1.16)$ & $-0.04(-0.70)$ & $-0.01(-0.08)$ & $-0.07(-1.10)$ \\
\hline Agricultural income & $0.01(0.06)$ & $-0.01(-0.29)$ & $-0.01(-0.17)$ & $-0.01(-0.35)$ \\
\hline Nonagricultural income & $-0.01(-0.57)$ & $-0.01(-0.04)$ & $-0.01(-0.48)$ & $-0.01(-0.02)$ \\
\hline Fixed assets & $0.06(1.57)$ & $0.15(2.20)$ & $0.05(1.41)$ & $0.15(2.09)$ \\
\hline Water endowment & $-0.14(-1.06)$ & $-0.31 *(-1.85)$ & $-0.16(-1.22)$ & $-0.31(-1.86)$ \\
\hline Geographical endowment & $0.18 *(1.67)$ & $0.87^{* * *}(6.60)$ & $0.21^{* *}(1.96)$ & $0.86 * * *(6.65)$ \\
\hline Land scale & $-0.05(-1.55)$ & $-0.16^{* * *}(-3.97)$ & $-0.04(-1.43)$ & $-0.15^{* * *}(-3.74)$ \\
\hline Communist Party member & $0.09(0.52)$ & $0.01(0.01)$ & $0.11(0.61)$ & $-0.02(-0.01)$ \\
\hline Expenditures on gifts & $0.24(1.32)$ & $0.11 （ 1.18)$ & $0.24(1.21)$ & $0.09(1.04)$ \\
\hline Local development level & $-0.21(-0.74)$ & $0.19(0.58)$ & $-0.41(-1.46)$ & $0.10(0.34)$ \\
\hline Traffic condition & $0.21^{* * *}(2.62)$ & $0.12(1.12)$ & $0.20 * *(2.55)$ & $0.12(1.18)$ \\
\hline Con & $-1.60(-0.52)$ & $-7.19 *(-1.87)$ & $1.38(0.47)$ & $-5.97(-1.60)$ \\
\hline Pseudo R2 & 0.15 & 0.18 & 0.23 & 0.39 \\
\hline
\end{tabular}

Non-farmer has a positive and significant impact on rent out intention, but not significant on rent out behavior. Non-farmers mainly depend on nonagricultural income, land is not important for them anymore, thus they tend to rent out. It is important to mention that under the current agricultural subsidy policy framework, non-farmers can get agricultural subsidies if they have the land contract right, even if they have no farming activity at all. At the same time, lack of land rental market led to information asymmetry, low rent and complex procedures of land transfer. Moreover,in the case that social security system is not perfect, land still plays the role as social insurance at some extent, so land transfer behavior of non-farmers is not significant. Further survey was conducted on non-farmers who want to rent out land but haven't. The results show that 32 farmers do not know who wants to rent in land, 100 farmers think the rent is too low, and 78 farmers consider negotiating with other farmers are difficult, accounting for 23.88 percent, 74.62 percent, and 58.20 percent of the sample respectively. These facts indicate that asymmetric information, low rent and complex procedures will impede the land transfer of non-farmers. In addition, there are 45 farmers worry about that they can't receive rent finally, this implies that social security function of land is also one of the reasons that prevent non-farmers from renting out land. Facts above verify the accuracy of hypothesis 4.

Table 7 below reports the estimates of rent in intention and behavior of non-full-time farmers (i.e. part-time farmers and non-farmers), both have negative impact on the land rent in intention and behavior. Based on the afore-mentioned analysis, land is no longer an important productive factor for them: part-time farmers tend to maintain the land scale for self-consumption and devote more endowment to non-agriculture business, while non-farmers stay out all-year and do not want to rent in as their dependence on land are diminishing constantly. 
Table 7 The rent in intention and behavior of non-full-time farmers.

\begin{tabular}{|c|c|c|c|c|}
\hline \multirow{2}{*}{ Variables } & \multicolumn{2}{|c|}{ Part-time farmers } & \multicolumn{2}{|c|}{ Non-farmers } \\
\hline & Rent in intention & Rent in behavior & Rent in intention & Rent in behavior \\
\hline Part-time farmer & $-0.88 * * * \quad(-3.96)$ & $-0.23(-1.01)$ & - & - \\
\hline Non-farmer & - & - & $-0.47(-1.32)$ & $-1.99 * * *(-2.71)$ \\
\hline Gender & $0.85(1.61)$ & $0.35(0.67)$ & $0.75(1.40)$ & $0.34(0.63)$ \\
\hline Age & $-0.03 * * * \quad(-3.68)$ & $0.02 * *(2.33)$ & $-0.03 * * *(-3.17)$ & $0.02 * *(2.34)$ \\
\hline Education & $-0.20(-1.64)$ & $-0.19(-1.43)$ & $-0.20(-1.58)$ & $-0.17(-1.28)$ \\
\hline Family size & $-0.13^{*}(-1.80)$ & $0.10(1.28)$ & $-0.04(-0.57)$ & $0.17 * *(2.02)$ \\
\hline Agricultural income & $0.01(0.62)$ & $0.01(0.37)$ & $0.02(0.89)$ & $0.01(0.40)$ \\
\hline Nonagricultural income & $0.01(0.12)$ & $0.05(1.12)$ & $0.01(0.14)$ & $0.05(1.10)$ \\
\hline Fixed assets & $-0.04(-0.72)$ & $0.14 *(1.82)$ & $-0.02(-0.35)$ & $0.16^{*}(1.92)$ \\
\hline Water endowment & $0.27(1.15)$ & $0.23(0.86)$ & $0.28(1.25)$ & $0.23(0.89)$ \\
\hline Geographical endowment & $0.93 * * * \quad(5.69)$ & $0.36^{* * *}(2.68)$ & $0.90 * * *(5.56)$ & $0.38 * * *(2.88)$ \\
\hline Land scale & $0.15^{* * *} \quad(5.17)$ & $0.06^{* *}(2.14)$ & $0.15^{* * *}(5.12)$ & $0.05(1.58)$ \\
\hline Communist Party member & $0.52 * * \quad(2.00)$ & $-0.43(-1.23)$ & $0.49 *(1.91)$ & $-0.38(-1.10)$ \\
\hline Expenditures on gifts & $0.01(0.07)$ & $-0.07 *(-1.81)$ & $-0.02(-0.40)$ & $-0.07 *(-1.64)$ \\
\hline Local development level & $-0.82 * * \quad(-2.17)$ & $-0.10(-0.25)$ & $-0.59(-1.58)$ & $-0.01(-0.04)$ \\
\hline Traffic condition & $-0.26 * *(-2.11)$ & $-0.12(-0.91)$ & $-0.25 * *(-1.99)$ & $-0.13(-1.00)$ \\
\hline Con & $6.90 *(1.83)$ & $-5.34(-1.28)$ & $3.58(0.97)$ & $-6.81(-1.55)$ \\
\hline Pseudo R2 & 0.16 & 0.27 & 0.14 & 0.29 \\
\hline
\end{tabular}

\subsection{Comparative analysis of land transfer intention and behavior of full time farmers and} non-full-time farmers

\subsubsection{Econometric model}

In this section there are two subsections. The first one reports the results of a comparative analysis of the land rent in intention and behavior of full time farmers. The second one reports the results of a comparative analysis of the rent out intention and behavior of non-full-time farmers. In order to estimate the differences between full time farmers on renting in intention and behavior, we specify the following empirical model:

$$
\begin{array}{r}
R I_{i}=\alpha_{i}+\beta_{i} F+\text { Cons }_{i}+\mu_{i} \\
R O_{j}=\alpha_{j}+\beta_{j} N+\text { cons }_{j}+\mu_{j}
\end{array}
$$

In equation (12), $\alpha_{i}$ denotes the fixed effect; $R I$ denotes rent in; $F$ is a dummy variable, which equals 1 if the household is a new agricultural business entity and equals 0 if the household is a smallholder; cons a set of control variables; $\mu$, the error term; subscript $i=1,2,1$ denotes transfer intention and 2 denotes transfer behavior.

In equation (13), ${ }^{\alpha}$ denotes the fixed effect; $R O$ denotes rent out; $N$ is a dummy variable, which equals 1 if the household is a non-farmer and equals 0 if the household is a part-time farmer; cons a set of control variables; $\mu$, the error term; subscript $j=1,2,1$ denotes transfer intention and 2 denotes transfer behavior. 


\subsubsection{Comparative analysis of rent in intention and behavior of full time farmers}

As table 8 above shows, the impact coefficient of household type on renting in intention is 1.348, which means when other things be equal, the rent out intention of new agricultural business entities are 34.8 percent higher than smallholders. The impact coefficient of household type on renting in behavior is 2.049, that is, the rent out intention of new agricultural business entities are 104.9 percent higher than smallholders. These facts imply that new agricultural business entities not only have a stronger rent in intention than smallholders, but also can rent in land much easier. The reasons are as follows: unlikely the small-scale, subtle operation of smallholders, new agricultural business entities need to rent in large area of land to meet the requirements of professional and large-size operation. Hence, the rent in intention of them is higher than smallholders. In addition, higher profit margin owes to modern management, coupled with policies support provided by government allow them to rent in land much easier.

Table 8 Comparative analysis of Land transfer intention and behavior of full time farmers.

\begin{tabular}{|c|c|c|c|c|}
\hline \multirow{2}{*}{ Variables } & \multicolumn{2}{|c|}{ Rent in intention } & \multicolumn{2}{|c|}{ Rent in behavior } \\
\hline & Odds ration & Marginal effect & Odds ration & Marginal effect \\
\hline Household type & $1.348(0.61)$ & $0.028(0.61)$ & $1.291(0.39)$ & $0.013(0.38)$ \\
\hline Gender & $1.028(0.04)$ & $0.003(0.04)$ & $0.654(-1.35)$ & $-0.079(-1.35)$ \\
\hline Age & $0.974(-1.30)$ & $-0.002(-1.31)$ & $0.979 * *(-2.45)$ & $-0.004 * *(-2.48)$ \\
\hline Education & $0.941(-0.27)$ & $-0.006(-0.27)$ & $1.001(0.01)$ & $0.000(0.01)$ \\
\hline Family size & $1.297 *(1.85)$ & $0.024 *(1.87)$ & $0.887 *(-1.78)$ & $-0.022(-1.79)$ \\
\hline Total income & $1.171(0.11)$ & $0.003(0.11)$ & $1.180(1.45)$ & $0.031(1.46)$ \\
\hline Fixed assets & $0.694^{* *}(-1.99)$ & $-0.034 * *(-2.03)$ & $0.951(-0.67)$ & $-0.009(-0.67)$ \\
\hline Water endowment & $0.739(-0.93)$ & $-0.028(-0.94)$ & $1.289 *(1.73)$ & $0.047 *(1.74)$ \\
\hline Geographical endowment & $5.735 * * *(5.01)$ & $0.164^{* * *}(5.69)$ & $1.247 * *(1.98)$ & $0.041 * *(2.00)$ \\
\hline Land scale & $1.114^{* * *(4.06)}$ & $0.010^{* * *}(4.51)$ & $1.002(0.13)$ & $0.000(0.13)$ \\
\hline Communist Party member & $1.447(0.81)$ & $0.035(0.81)$ & $1.138(0.64)$ & $0.024(0.64)$ \\
\hline Expenditures on gifts & $1.230(0.94)$ & $0.019(0.95)$ & $1.183 *(1.94)$ & $0.031 *(1.95)$ \\
\hline Local development level & $0.315(-1.37)$ & $-0.108(-1.38)$ & $0.776(-0.85)$ & $-0.047(-0.85)$ \\
\hline Traffic condition & $0.757(-1.21)$ & $-0.026(-1.22)$ & $1.157(1.47)$ & $0.027(1.48)$ \\
\hline Con & $3.278(1.21)$ & - & $0.659(-0.13)$ & - \\
\hline Likelihood & \multicolumn{2}{|c|}{-86.682} & \multicolumn{2}{|c|}{-95.939} \\
\hline Pseudo $\mathrm{R}^{2}$ & \multicolumn{2}{|c|}{0.324} & \multicolumn{2}{|c|}{0.261} \\
\hline
\end{tabular}

\subsubsection{Comparative analysis of rent in intention and behavior of non-full-time farmers}

As table 9 below shows, the impact coefficient of household type on rent-out intention is 1.291, which means that the rent in intention of non-farmers is 29.1 percent higher than part-time farmer. But the impact coefficient of household type on renting out behavior is 0.835 , which means that the rent out intention of non-farmers is 16.5 percent lower than part-time farmers. These facts imply that non-farmers have stronger rent out intention than part-time farmers, but their rent out intention did not turn into rent out behavior correspondingly. Compared with part-time farmers, non-farm farmers' business has nothing to do with land, their dependence on agricultural income is relative low, renting out intention of them is stronger than part-time farmers. However, in the absence of land rental market and social security system, non-farmers will neither willing nor able to transfer land easily. Meanwhile, since part-time farmers still engaged in agricultural operation, they can get more information about land transfer than non-farmers, so they can rent out land more convenient. 
Table 9 Comparative analysis of Land transfer intention and behavior of non-full-time farmers.

\begin{tabular}{|c|c|c|c|c|}
\hline \multirow{2}{*}{ Variables } & \multicolumn{2}{|c|}{ Rent in intention } & \multicolumn{2}{c|}{ Rent in behavior } \\
\cline { 2 - 5 } & Odds ration & Marginal effect & Odds ration & Marginal effect \\
\hline Household type & $0.835(-0.82)$ & $-0.024(-0.82)$ & $2.049(1.54)$ & $0.075(1.56)$ \\
\hline Gender & $0.489^{* *}(-2.02)$ & $-0.094^{* *}(-2.03)$ & $0.977(-0.03)$ & $-0.002(-0.03)$ \\
\hline Age & $0.998(-0.21)$ & $-0.000(-0.21)$ & $1.008(0.39)$ & $0.001(0.39)$ \\
\hline Education & $1.082(0.64)$ & $0.010(0.65)$ & $0.764(-1.26)$ & $-0.028(-1.26)$ \\
\hline Family size & $0.908(-1.19)$ & $-0.013(-1.19)$ & $1.254^{*}(1.66)$ & $0.024(1.68)$ \\
\hline Total income & $1.027(0.21)$ & $0.004(0.21)$ & $1.485(1.46)$ & $0.041(1.47)$ \\
\hline Fixed assets & $1.027(0.29)$ & $0.004(0.29)$ & $0.804(-1.13)$ & $-0.023(-1.13)$ \\
\hline Water endowment & $1.409^{*}(1.88)$ & $0.045^{*}(1.89)$ & $0.638(-1.46)$ & $-0.047(-1.48)$ \\
\hline Geographical endowment & $2.013^{* * *}(4.76)$ & $0.092(4.85)$ & $1.350(1.01)$ & $0.031(1.01)$ \\
\hline Land scale & $0.919^{* * *}(-2.78)$ & $-0.011^{* *}(-2.80)$ & $1.089^{* * *}(3.76)$ & $0.009^{* * *}(4.13)$ \\
\hline Communist Party member & $1.306(1.14)$ & $.0349573(1.14)$ & $0.591(-1.10)$ & $-0.055(-1.11)$ \\
\hline Expenditures on gifts & $0.927(-0.72)$ & $-0.010(-0.72)$ & $0.683 *(-1.86)$ & $-0.039^{*}(-1.89)$ \\
\hline Local development level & $1.228(0.58)$ & $0.027(0.58)$ & $2.825(1.23)$ & $0.108(1.23)$ \\
\hline Traffic condition & $1.034(0.27)$ & $0.004(0.27)$ & $1.315(1.11)$ & $0.029(1.11)$ \\
\hline Con & $0.009(-1.24)$ & - & $1.476(1.63)$ & - \\
\hline Likelihood & -469.515 & & -356.864 \\
\hline Pseudo R ${ }^{2}$ & \multicolumn{2}{|c|}{0.036} & & 0.072 \\
\hline
\end{tabular}

\section{Conclusion}

Driven by reform and opening up policy and Household Contract Register System reform, the Chinese agricultural labor force begun to migrate to urban areas and nonagricultural sectors. Traditional smallholders have stratified into smallholders, new agricultural business entities, part-time farmers and non-farmers. This paper examines land transfer intention and behavior of them based on the micro-survey data for statistical analysis and empirical test, the results show that:

(1) Smallholders mainly rely on agricultural income, and land is an important production factor for them, under the current land system framework, its operating scale is far below the optimal scale level. They have a strong willingness to transfer land, but the information asymmetry and high transaction costs hinder their behavior.

(2) New agricultural business entities have stronger willingness of land transfer than the smallholders, because their optimal land scale are larger than smallholder's, moreover, they can rent in land much easier, because they can afford relatively high land rents and get governmental support.

(3) Part-time farmers tend to maintain the land scale based on marginal output flattening effect.in addition, the asymmetry of information and the uncertainty of social security have restricted their behavior of land transfer.,

(4) Non-farmers have the weakest dependence on land, and their willingness to transfer land is strong. However, the current distorted subsidy policy, information asymmetry, together with low land rents, complex procedures of land transfer and high transaction costs of land have greatly hampered their rent out behavior.

According to the above analysis, the policy implications are mainly as follows:: First and foremost, the Chinese government should create a better economic conditions for the transformation of agricultural modernization and orderly circulation of land, for instance, accelerate research speed on various incentive policies in the occupational differentiation of rural household, together with establish differentiated investment induction policies for innovation and entrepreneurship for the four types of farmers.

Secondly, exert the positive role of market mechanism in the circulation of land management rights, speed up the establishment of rural land exchanges with the country as the center, introduce the land internet trading platform and cultivate rural land circulation service agencies, and then eliminate the asymmetry of land transfer information, reduce transaction costs, and create favorable market conditions for the transfer of farmer land ownership rights.

Thirdly, expand the effective demand of new agricultural business entities for land transfer, actively cultivate high-quality agricultural projects based on the endowment of local agricultural 
resources, develop agricultural parks, actively attract investment, orderly guide urban capital to the countryside, and cultivate and expand new types of agricultural business entities. In addition, the government should strengthen supply-side reform of agriculture, timely study the postponement of land management rights for new-type agricultural business entities after the expiration of the second round of land contractual management rights in year 2028, and encourage long-term investment.

Moreover, establish an urban-rural integration social security system, speed up the preferential policies for migrant farmers to purchase houses in cities and towns, and expand the effective supply level of farmland circulation.

Last but not least, reform grain subsidy system, truly achieve "who grows grain, who benefits" and ensure the incentive effect of subsidy funds on farmers, the relative government department should change the existing misallocation pattern of subsidy resources such as "not benefit from grain production" and "gain benefit without grain" in some regions.

Through the above suggestions, the government will guide the occupational differentiation of farmers and improve the supply and demand structure of rural areas, so as to promote the moderate scale of agricultural operation, and further promote the realization of agricultural modernization and a moderately prosperous society.

\section{Note}

(1) New agricultural business entity is the official title for big-specialized-households of crop and animal productions, household farms, cooperatives and agricultural enterprises in China.

(2) It refers to the household which work on farming during busy farming season and work in non-farming sector during the other time of the year.

(3) It refers to the transfer ratio of cultivated land.

(4) $1 \mathrm{mu}=0.0667$ hectare

(5) We assume that farmers will only consider their accounting profit given their operational characteristics.

\section{Acknowledgement}

This research was funded by Guizhou University of Finance and Economics Green Finance Research Project "Research on the Impact Mechanism of Green Finance on Economic Development_—_Taking Guizhou Province as an Example" (Grant Number: 2019DYL01).

\section{References}

[1] Cai F \& Du Y. (2003) The development of China cities in transition: the structure of urban class, the ability of financing and the migration policies. Economic Research Journal 6: 64-71+95. (in Chinese)

[2] He X \& Dong L. (2009) The logic of peasant's work in the city and the path of Chinese urbanization. China Rural Survey 2: 12-18+95. (in Chinese)

[3] Deininger K \& Jin S. (2006) Tenure security and land-related investment: evidence from Ethiopia. European Economic Review 50: 1245-1277.

[4] Jin S \& Deininger K. (2007) Land rental markets in the process of rural structural transformation: productivity and equity impacts from China. Journal of Comparative Economics 37(4):629-646.

[5] Luo B, He Y, Wang S \& You N. (2012) Land contract management right: analysis of peasants' quit intention and its influencing factors-based on the peasants' questionnaire in Guangdong Province. Chinese Rural Economy 6: 4-19. (in Chinese) 
[6] Huang F \& Sun S. (2015) Let the market allocation agricultural land resources: labor force transfer and development of land rental markets. Management World 7: 71-81. (in Chinese)

[7] Demsetz H. (1974) Toward a theory of property rights. Palgrave Macmillan UK Press, UK.

[8] Besley T. (1995) Property rights and investment incentives: theory and evidence from Ghana. Journal of Political Economy 103: 903-937.

[9] Alchian A \& Demsetz H. (1973) The property right paradigm. The Journal of Economic History 33: 16-27.

[10] Zhu M, Wei A \& Liu S. (1997) Land system and land investment under household responsibility system. Economic Research Journal 10: 62-69. (in Chinese)

[11] Huang J. (2012) China’s rural land system, rural land transfer and rural land investment. Gezhi Press, Shanghai. (in Chinese)

[12] Gao L, Huang J, Rozelle S \& Xu Z. (2011) Emerging rental markets and investment in agricultural land in China. China Economic Quarterly 4: 1499-1514. (in Chinese)

[13] Cheng L, Zhang H \& Liu Z (2016) Does rights confirmation of agricultural land promote the land transfer in China?. Management World 1: 88-98. (in Chinese)

[14] Qian Z. (2003) The market liquidity of contracting and operation right to rural land: a theoretical and empirical study. Economic Research Journal 2: 83-91+94. (in Chinese)

[15] Zhou Q. (2004) Property rights and land requisition system: a critical choice for China's urbanization. China Economic Quarterly 4: 193-210. (in Chinese)

[16] Janvry A, Gordillo G, Platteau J, et al. (2001) Access to land, rural poverty, and public action. Oxford University Press, Oxford.

[17] Feder G, Just R \& Zilberman D. (1985) Adoption of agricultural innovations in developing countries: a survey. Economic Development and Cultural Change 33: 255-298.

[18] Wu L, Li L \& Yao Y. (2014) The influence of agricultural tax reform on land transfer: a theoretical and empirical analysis based on state transition model. Chinese Rural Economy 7: 48-60. (in Chinese)

[19] Feder G. (1988) Land policies and farm productivity in Thailand. Johns Hopkins University Press, Maryland.

[20] Michael C \& Yao Y. (2004) Industrialization, land lease markets, and agricultural investment. China Economic Quarterly 3: 983-1002. (in Chinese)

[21] Feng T \& Yang Z. (2013) The forecast of new type rural pension funds which land transfer introduction. The Journal of Quantitative and Technical Economics 6: 3-18. (in Chinese)

[22] Zhang J, Liu J \& Xu Q. (2016) The new cooperation medical schemes, land transfer and land retention. Management World 1: 99-109. (in Chinese)

[23] Brandt L, Huang J, Li G, et al. (2002) Land rights in rural China: facts, fictions and issues. The China Journal 47: 67-97.

[24] Huang J \& Rozelle S. (1996) Technological change: the re-discovery of the engine of productivity growth in China's rural economy. Journal of Development Economics 49: 337-369. 